\title{
Suitability of Macrophytes for Wastewater Treatment and Biogas Generation
}

\author{
S.Vanitha, C.Sivapragasam
}

\begin{abstract}
In this paper three sustainable approaches are made in waste management option. Firstly primary treated domestic sewage is treated by aquatic macrophytes using duckweed, water hyacinth and water lettuce. Biochemical Oxygen Demand (BOD), Chemical Oxygen Demand (COD), Total Suspended Solids (TSS), Total Dissolved Solids (TDS), Phosphate, Nitrates are tested before and after. Result indicates in terms of water quality, almost all three plants shows same removal efficiencies. BOD and TSS removal efficiency is attained more than 95\%. COD and TDS removal is reached upto $50 \%$ for almost all plants. Secondly the used aquatic macrophytes for wastewater treatment is again used for generation of biogas (water lettuce unit, duckweed unit, water lettuce unit). In addition to three aquatic macrophytes, sludge is collected from aquatic macrophyte unit for generation of biogas. Comparison is made with conventional cow dung biogas unit. Result indicates water lettuce and duckweed produce biogas at earlier stage itself and water hyacinth takes some time for starting of biogas production. This may be due to the structure and texture causes some time for decomposition. Sludge gives maximum biogas generation among all experimental setup. Also in this study cow dung did not give biogas more may be due to poor blend ratio of cow dung with water is one of the reason.
\end{abstract}

Keywords : domestic sewage, Aquatic plants, biogas, spinach plant.

\section{INTRODUCTION}

Due to population increase, life style of people, industrialization is the main reason for consumption of more energy. Lack of fossil fuels increase cost of fuel price. Also fossil fuels exploites environment namely global warming and acid rain. Now there is a need of urge towards identifying alternative energy resources [1].

Already many researchers did work on biogas production.[1] discussed duckweed can be utilized to produce biogas because of rich in N,P and high biomass yield. [3] found water hyacinth, water chesnut have been used for production of biogas. [2] discussed poultry dropping, cow dung and lemon grass were compared for higher production of biogas and it is found poultry droppings produce more biogas as well as lemon grass produced less biogas. But quality of biogas using lemon grass is good.

In this study sustainable approach is made twofold by adopting low cost wastewater treatment using aquatic macrophytes and to utilize the used aquatic macrophytes from wastewater treatment is taken for biogas generation to avoid

Revised Manuscript Received on December 13, 2019.

* Correspondence Author

Dr.S.Vanitha, department of Civil Engineering, Kalasalingam Academy of Research and Education, Krishnankoil, India. Email:svanithacivil@gmail.com.

Dr.C.Sivapragasam*,Center of water technology, department of Civil Engineering, Kalasalingam Academy of Research and Education, Krishnan kovil, Tamilnadu, India..Email: sivapragasam@klu.ac.in environmental degradation. The sludge produced from wastewater treatment is also used for biogas production. Comparison is made with convention cow dung biogas treatment unit which will helpful for identifying the performance of aquatic macrophytes units in gas production.

\section{METHODOLOGY}

In this study two eco friendly approaches have been made. First approach is wastewater treatment is done by natural plants (macrophyte). Second the aquatic plant is used wastewater treatment is used for generation of biogas. The following two approaches are discussed below

\section{A. Treatment of Sewage using Aquatic Plants.}

Aquatic plants Pistia stratiotes (Water Lettuce), Lemna minor (Duckweed) and Eichhornia crassipes (Water hyacinth) are collected from fresh pond located at Virudhunagar district. Plants were thoroughly cleaned by distilled water. Initially aquatic macrophytes are introduced into primary treated sewage of 40 litres. $\mathrm{pH}$, Biochemical Oxygen Demand (BOD), Chemical Oxygen Demand(COD), Total Suspended Solids (TSS), Total Dissolved Solids (TDS), Phosphate, Nitrates are tested before and after treatment. Fig. 1 explains the overall view of utilization of aquatic macrophytes for wastewater treatment and biogas production.

\section{B. Utlization of aquatic macrophytes for generation of biogas}

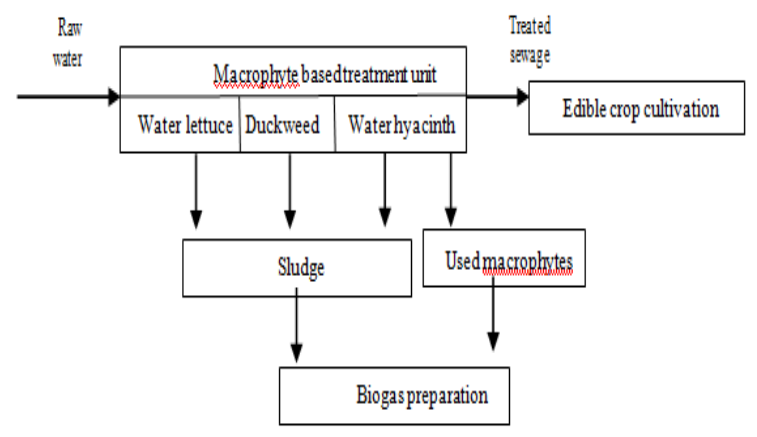

Fig. 1.Flowsheet of utilization macrophytes for sustainable approach

After treatment of wastewater, the aquatic plants have been collected for generation of biogas. Totally five experimental setup are made. In first setup cow dung is taken. In second setup sludge is taken. Chopped aquatic macrophytes such as water lettuce, duckweed and water hyacinth are taken in third, fourth and fifth experimental containers respectively. 
In all five containers, $10 \mathrm{ml}$ cow dung is added for enhancing bacterial decomposition. All containers have been made as airtight to enhance anaerobic digestion. Volume of gas production has been measured by water displacement method. Fig 2 shows the experimental setup of lab scale biogas units. The gas collection is monitored in all containers

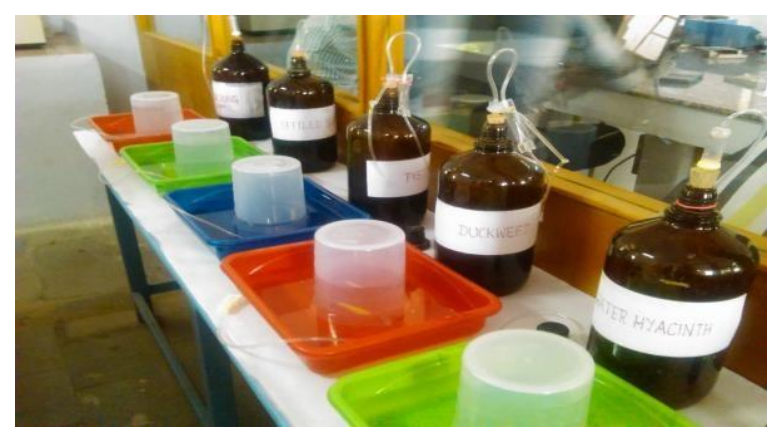

once in two days for thirty day period.

Fig 2. Experimental set up of laboratory scale biogas unit

\section{RESULT AND DISCUSSION}

Treatment of sewage using aquatic macrophytes

Table 1 explains the quality of water before and water treatment in three macrophyte unit. The overall removal removal efficiency of BOD, COD, TSS, TDS, phosphate and nitrate values are shown in Table 2 . It is seen that the the BOD, TSS are removed well in all treatment unit and it obtained more than $95 \%$. The COD and TDS removal is obtained upto $50 \%$. Nitrate removal is maximum in duckweed unit and it is $88 \%$. Phosphate removal is almost $30 \%$ in all treatment units.

Table- I: Water Quality Before and After Treatment In Macrophytes Based Wastewater Treatment

\begin{tabular}{|c|c|c|c|c|c|}
\hline \multirow[b]{2}{*}{$\underset{\dot{n}}{z}$} & \multirow{2}{*}{$\begin{array}{c}\text { Water } \\
\text { quality } \\
\text { paramete } \\
\mathbf{r}\end{array}$} & \multirow{2}{*}{$\begin{array}{c}\text { Befo } \\
\text { re } \\
\text { treat } \\
\text { ment }\end{array}$} & \multicolumn{3}{|c|}{ After treatment (mg/l) } \\
\hline & & & $\begin{array}{l}\text { Water } \\
\text { lettuce }\end{array}$ & $\begin{array}{c}\text { Duckw } \\
\text { e ed }\end{array}$ & $\begin{array}{c}\text { Water } \\
\text { hyacin } \\
\text { th }\end{array}$ \\
\hline 1 & $\mathrm{pH}$ & 7.88 & 7.81 & 7.56 & 7.32 \\
\hline 2 & BOD & 150 & 8 & 6 & 2 \\
\hline 3 & COD & 496 & 320 & 288 & 256 \\
\hline 4 & TSS & 1630 & 12 & 4 & 28 \\
\hline 5 & TDS & 1093 & 467 & 568 & 642 \\
\hline 6 & Phosphate & 10.93 & 7.81 & 7.56 & 7.32 \\
\hline 7 & Nitrate & 10.01 & 3.32 & 1.10 & 3.32 \\
\hline
\end{tabular}

Table- II: Percentage removal in Macrophyte Based Wastewater Treatment

\begin{tabular}{|c|c|c|c|c|c|}
\hline \multirow[b]{2}{*}{$\sum_{\dot{s}}$} & \multirow{2}{*}{$\begin{array}{c}\text { Water } \\
\text { quality } \\
\text { paramete } \\
\text { r }\end{array}$} & \multirow{2}{*}{$\begin{array}{c}\text { Before } \\
\text { treat } \\
\text { ment } \\
(\mathrm{mg} / \mathrm{l})\end{array}$} & \multicolumn{3}{|c|}{ Percentage removal (\%) } \\
\hline & & & $\begin{array}{l}\text { Water } \\
\text { lettuce }\end{array}$ & $\begin{array}{c}\text { Duckwe } \\
\text { ed }\end{array}$ & $\begin{array}{c}\text { Water } \\
\text { hyaci } \\
\text { nt h }\end{array}$ \\
\hline 1 & $\mathrm{pH}$ & 7.88 & 7.81 & 7.56 & 7.32 \\
\hline 2 & BOD & 150 & 94.66 & 96.00 & 98.66 \\
\hline 3 & $\mathrm{COD}$ & 496 & 35.48 & 41.93 & 48.38 \\
\hline 4 & TSS & 1630 & 99.26 & 99.75 & 98.28 \\
\hline 5 & TDS & 1093 & 57.27 & 48.03 & 41.26 \\
\hline 6 & Phosphate & 10.93 & 28.54 & 30.83 & 33.02 \\
\hline 7 & Nitrate & 10.01 & 66.83 & 89.01 & 66.83 \\
\hline
\end{tabular}

\section{Gas production using Aquatic macrophytes}

Table 3 shows the volume of gas production in five experimental setup. It is found that gas production in water lettuce unit is started from second day itself and almost ends at tenth day. After ten days no more generation of bio gas was observed because of complete digestion of plants by anaerobic bacteria for biogas production. It is observed that the gas production is quicker in water lettuce tank than other containers. In sludge tank it is observed that the gas production is obtained till end of experimental period as well as the gas production is fluctuating throughout the study period. In duckweed unit at initial periods the gas production is higher than later period. The gas production is higher till sixteenth day. Afterwards it start to decrease. In water hyacinth unit initial days very less gas production is observed. In the middle of the Experimental period maximum gas production is obtained.

Table- III: Gas Production at Different Time Period

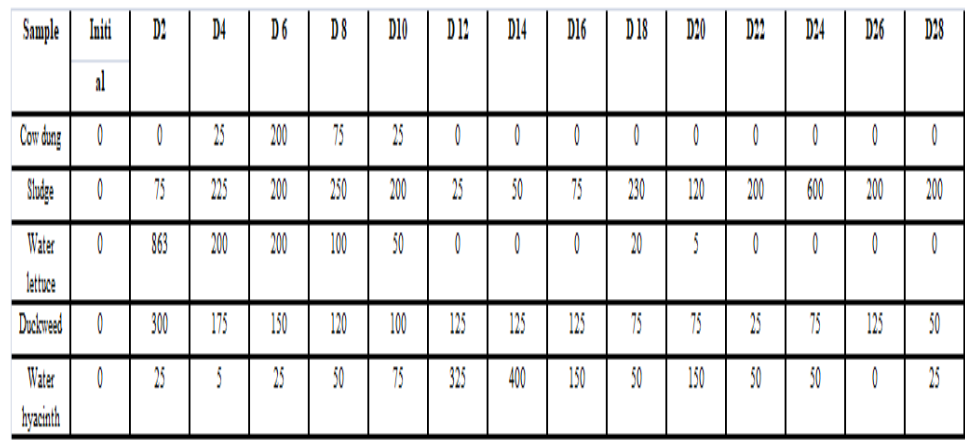

After eighteenth day the gas production is reduced. The increase in gas production in duckweed and water lettuce in earlier days is due to structure and texture of plants is easily decomposed by bacteria whereas in water hyacinth the structure is hard and it is difficult to decompose may be one of the reason that gas production is not attained at earlier days Among five containers cow dung generates less volume of biogas. This may be due to improper mix proportion of cow dung with water. [4] discussed rate of biogas in water hyacinth is more than cow dung. This corroborates our findings. [5] found dairy manure slurry with the addition of duckweed enhancing biogas production. From Table 4 it is understood that the maximum generation of gas is in sludge container as $2650 \mathrm{ml}$. It is a known fact that sludge contains rich in microorganisms which may support the anaerobic decomposition also.

TABLE - IV : Total Gas Productions in Experimental

\begin{tabular}{|c|c|c|}
\hline S.No & Sample & $\begin{array}{c}\text { Total gas } \\
\text { produced (ml) } \\
\text { after 28 days }\end{array}$ \\
\hline 1 & Cow dung & 325 \\
\hline 2 & Sludge & 2650 \\
\hline 3 & Water lettuce & 1438 \\
\hline 4 & Duckweed & 1645 \\
\hline 5 & Water hyacinth & 1380 \\
\hline
\end{tabular}

UTILIZED OF TREATED WASTEWATER FOR GROWING SPINACH 
Treated wastewater is collected and it is used for growing edible (spinach) plant. Two plots are made and seeds are spread. Daily watering is done using tap water and treated wastewater for first plot and second plot respectively. Growth of plant is monitored for thirty days. The growth of the plant using treated wastewater is compared with plant grown in ordinary tap water. Fig. 3 shows different growth stages of spinach plant grown in tap water and treated water respectively. After 45 days, spinach plant growth in treated wastewater is compared plants growing in tap water. Interestingly the spinach growth is better in treated wastewater than normal tap water because of higher nutrient present in treated wastewater

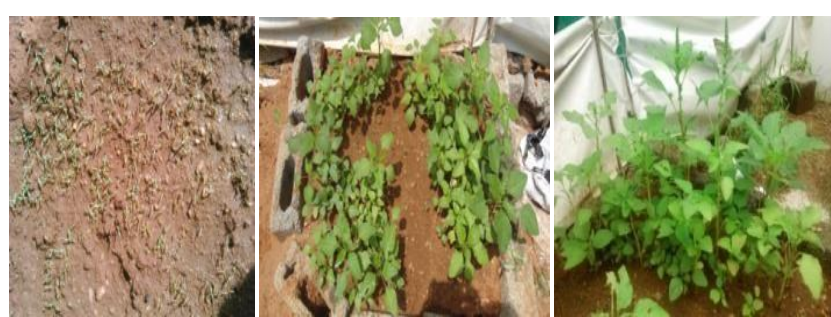

Fig 3.Growth stages of spinach plant in tap water and treated wastewater

\section{CONCLUSION}

In this two approaches are made. In first study, sewage is treated by water lettuce, duckweed and water hyacinth. Result indicated BOD and TSS removal is obtained more than $95 \%$ in all treatment units. Removal of TDS and COD is obtained till $50 \%$. Nitrate removal is well in duckweed treatment unit. In second approach Sewage sludge, cow dung, aquatic weed such as water lettuce, duckweed and water hyacinth are used for production of biogas. Among this sludge, duckweed, water lettuce, water hyacinth generates volume of $2650 \mathrm{ml}, 1645 \mathrm{ml}, 1438 \mathrm{ml}$ and $1380 \mathrm{ml}$ respectively. Cow dung generates less volume of biogas as $325 \mathrm{ml}$. This may be due poor blend ratio of cow dung with water. Initial stage itself generation of biogas is more in water lettuce unit. After tenth day cow dung and water lettuce container no biogas generation was observed. Duckweed unit generates more biogas at initial period than end of experimental period. Water hyacinth unit takes time for initiating the production of bio gas. This may be due the structure and texture of plant is one $f$ the reason for delaying in starting of gas production. Duckweed leaves are vey fine and easily decomposable than hyacinth and water lettuce.

\section{ACKNOWLEDGMENT}

The authors sincerely thank Karthick seenivasan, R.Manoj Prabakar, P.Mariswaran, C.Maruthupandi for help rendered for experimental studies.

\section{REFERENCES}

1. W. Cui, J.J. Cheng, "Growing duckweed for biofuel production: a review”, Plant biology, Vol.17, 2014, pp16-23.

2. M Alfa, S.O. Dahunsi, O.T. Iorhemen, C.C. Okafor, Ajayi, "Comparitive evaluation of biogas production from poultry dropping, cowdung and lemon grass", Bioresource technology, Vol.157, 2014, pp. 270-277

3. V.K.Verma, Y.P.Singh, J.P.N.Rai, "Biogas production from plant biomass used for phytoremediation of industrial wastewater", Bioresource Technology, Vol.98, 2007, pp 1664- 1669

4. K. Nahar, "Biogas production from water hyacinth (Eichhornnia crassipes), Asian Journal of Applied Science and Engineering", Vol.1, No.1, 2012, pp 9-13

5. P. Triscari, S. Henderson, D. Reinhold, "Anaerobic Digestion of Dairy Manure Combined with Duckweed" An ASABE meeting presentation June-21-24, 2009.

\section{AUTHORS PROFILE}

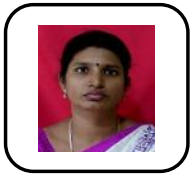

conferences.

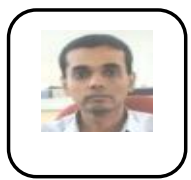

Dr. C.Sivapragasam has completed his graduation and post-graduation from IIT-Roorkee and IIT-Delh respectively. He completed his $\mathrm{PhD}$ from NUS, Singapore. He has 2 years of industry experience and more than 17 years of teaching experience. He has completed 3 sponsored research projects from various funding agencies and published more than 70 papers in peer reviewed journals and conferences
S.Vanitha has completed her graduation and post - graduation from Government of College of engineering, Tirunelveli and Arulmigu Kalasalingam College of Engineering. She has completed her $\mathrm{PhD}$ in Kalasalingam Academy of Research And Education. She has published more than 20 papers in journals and 